\title{
Development of Design Fires for Performance-Based Fire Safety Designs
}

\author{
GEORGE HADJISOPHOCLEOUS and EHAB ZALOK \\ Department of Civil and Environmental Engineering \\ Carleton University \\ 1125 Colonel By Drive \\ Ottawa, Ontario \\ Canada, K1S 5B6
}

\begin{abstract}
This paper discusses a procedure for the development of design fires for buildings and presents a study undertaken to quantify design fires for commercial buildings. This procedure includes building surveys, full-scale experiments and computer modelling. In this study, a survey of commercial premises was conducted to determine fire loads and types of combustibles present in these buildings. Based on the results of the survey a number of fuel packages were designed that represent fire loads and combustible materials in commercial buildings. The fuel packages were used to perform full-scale, post-flashover fire tests to collect data on heat release rates, compartment temperatures and production and concentration of toxic gases. Results from these experiments are presented and discussed. The paper also discusses a computer modelling study in which a computational fluid dynamics model was used to simulate the tests and to model a fire in a real-scale commercial store.
\end{abstract}

KEYWORDS: design fires, performance-based fire safety designs, fire loads INTRODUCTION

The introduction of performance/objective-based codes in many countries around the world has resulted in an increased use of engineering approaches to the design of fire protection systems in buildings. It has also prompted professional and standard writing bodies such as the ISO and SFPE to develop guidelines that provide guidance on the design process to be followed when using the performance-based approach for the design of fire protection systems in buildings. Guidelines, such as the SFPE Engineering Guide [1] and the International Fire Engineering Guidelines [2] clearly indicate that the task of identifying and selecting fire scenarios and design fires is an integral part of the design process. Other important tasks of the design process are: defining the project scope; establishing goals and objectives; and developing performance criteria. While the fire safety goals are expressed in general terms, the fire safety objectives delineate more specific ways of attaining these goals. Quantifiable performance criteria can then be selected to provide the basis for assessing whether fire protection designs achieve these objectives. To ensure that the design will satisfy the stated goals and objectives, the engineering analysis considers appropriate fire scenarios and associated design fires.

Design fires and design fire scenarios may have different meaning for different people. In ISO documents [3], a fire scenario is defined as a qualitative description of the course of a fire with time identifying key events that characterize the fire and differentiate it from other possible fires. It typically defines the ignition and fire growth process, the fully developed stage, and the decay stage together with the building environment and systems that may have an impact on the course of the fire. A design fire scenario is a specific fire scenario on which the analysis will be conducted, and a design fire is a quantitative description of assumed fire characteristics within the design fire scenario. Typically, an idealised description of the variation with time of important fire variables such as heat release rate, fire propagation, smoke and toxic species yield and temperature. The SFPE Guide defines the "design fire curve" as an engineering description of the development of a fire for a design fire scenario. Design fire curves might be described in terms of heat release rate versus time [1].

The concept of design fires and fire scenarios and their application in fire risk analysis have been discussed in Yung and Benichou [4]. The authors provide details of identifying design fire scenarios and design fires for residential buildings and their use in the fire risk analysis model FiRECAM [5]. As the authors state, six design fires can be used to represent all fires that may occur in residential and office buildings. They 
include three types of fires: smouldering fires; non-flashover flaming fires; and flashover fires, each with the compartment door being open or closed.

A description of the design fire and its components and the impact of each on the fire safety system are given by Thomas and Bennetts [6]. They discussed the different parts of the design fire (growth, fullydeveloped, and decay) that govern the behaviour and response of different components of the fire safety system. The rate of fire growth governs the time for the fire to be noticeable, for detectors to trigger alarms, and other fire safety components to be engaged (sprinklers to activate, etc.). The strength of the ignition source, and the form and type of the fuel initially ignited are the main factors that govern fire growth. The maximum heat release rate (HRR) and the duration of the fire, particularly the duration of the fully-developed fire, govern the response and the possible failure of different structural elements.

Rein et al. [7] presented an approach, which is still under development, to define design fires that can be used to evaluate the fire resistance of building elements. In their approach they considered distributed and travelling fires, as well as the fire load and ventilation conditions. They showed that, for a given fire load, a large fire will expose building elements to high temperatures for a shorter duration, whereas low intensity fires will expose building elements to lower temperatures for longer durations.

For building designs there is still a need to define design fires that can be acceptable by building officials and code authorities. The work presented in this paper deals with the identification and characterisation of design fires for commercial buildings. It describes the approach followed to estimate fuel loads and identify types of combustibles, the development of fuel packages, and the characterisation of the fires resulting from burning selected fuel packages. The paper also describes how the results of this study can be used to quantify design fires for specific applications using computer models.

\section{METHODOLOGY}

The approach for the development of design fires includes two main tasks: the identification of design fires and the quantification or characterisation of these fires. To identify design fires for a building it is necessary to consider the following parameters: fire loads; type of combustibles; arrangement of combustibles; building characteristics; geometry; and ventilation conditions. Fire loads, type and arrangement of combustibles are dependent on building usage and can be determined from building surveys. Building characteristics such as compartment geometry and ventilation conditions are design parameters. Type, surface area and distribution of combustibles affect the fire growth characteristics of the design fire, while the fire load governs the duration of the fire. Following the identification of design fires, the quantification process provides information on the heat release rate, time to flashover, production rate of toxic gases, area of the fire, hot layer temperature and fire duration.

The methodology that was used in this study to define design fires for commercial premises included the following tasks:

1. Building survey: A building survey was conducted to collect data on compartment size, fire load density, types of combustibles and fuel arrangement within compartments.

2. Statistical analysis: Available statistical data were analysed to determine the frequency of fires, ignition sources, and the most common location of fires occurring in commercial buildings.

3. Development of fuel packages: The survey data and statistical information were used to design fuel packages that represent the fire loads and combustibles in these buildings

4. Fully-developed fire tests: Full-scale, post-flashover fire tests were conducted to determine the burning characteristics of selected fuel packages.

5. Design fire characterisation: Based on the experimental data, appropriate design fires representing potential fires in commercial buildings were selected.

To assist the modelling of design fires using computational fluid dynamics models, two additional tasks have been undertaken.

- Preliminary experiments and modelling: Preliminary experiments using the developed fuel packages were conducted. The experimental data were used to develop representative fuel characteristics for 
input to the Fire Dynamics Simulator (FDS) [8] model such that the model predictions would compare favourably with the experimental data.

- Modelling of tests. Using the input data for the fuel packages determined above, FDS was employed to model the fully-developed fire tests and the model predictions were compared with the experimental data.

\section{FIRE LOADS}

A survey was conducted in the National Capital Region of Canada to characterize fire loads in commercial buildings. The survey included 168 commercial establishments, such as restaurants, bookstores, and shoe stores. The data collected were analyzed to determine the total fire load in each establishment, the fire load density, and the contribution of different combustible materials to the total fire load. Fire loads include both fixed and moveable combustible items within the compartment of fire origin. The location of combustible materials in a compartment is usually random, however, for some types of buildings both location and distribution of combustibles can be well defined [9]. The fire load is often expressed as an energy density (fire load per unit floor area) to enable the calculation of the fire load for compartments of different sizes. The design fire load for an enclosure is often a value chosen between the 80th and 95th percentile of the fire load that is not likely to be exceeded during the service life of a building [10]. The contribution of combustible construction materials to the fire load is not included in this study. Although for some buildings this may be significant, construction materials were outside the scope of this study.

The total fire load can be computed using the following equation;

$$
\mathrm{Q}=\sum \mathrm{k}_{\mathrm{i}} \mathrm{m}_{\mathrm{i}} \mathrm{h}_{\mathrm{c}_{\mathrm{i}}}
$$

Where $Q=$ total fire load in a compartment (MJ), $k_{i}=$ the proportion of content i that can burn, $m_{i}=$ the mass of content $i$ in the compartment $(\mathrm{kg}), \mathrm{h}_{\mathrm{c}_{\mathrm{i}}}=$ the calorific value of content $\mathrm{i}(\mathrm{MJ} / \mathrm{kg})$.

The fire load density is the total fire load divided by the floor area of the compartment:

$Q^{\prime \prime}=Q / A_{f}$

Where, $\mathrm{A}_{\mathrm{f}}=$ the area of the compartment floor $\left(\mathrm{m}^{2}\right)$ and $Q^{\prime \prime}=$ fire load density $\left(\mathrm{MJ} / \mathrm{m}^{2}\right)$.

Many European references express fire load as the energy density per square meter of the compartment's internal boundaries, which is the sum of all internal surface areas of the fire compartment including walls, floor and ceiling. In this paper, the fire load density is based on the floor area of a compartment. Calorific values for some of the combustibles that are usually found in stores can be found in [11,12]. Details of the survey methodology can be found in [13].

Figure 1 shows the frequency distribution of the fire load densities of the 168 surveyed stores. It can be seen that the fire load density has a lognormal distribution with a mean of $747 \mathrm{MJ} / \mathrm{m}^{2}$, a maximum of $5,305 \mathrm{MJ} / \mathrm{m}^{2}$, a minimum of $56 \mathrm{MJ} / \mathrm{m}^{2}$ and a standard deviation of $832 \mathrm{MJ} / \mathrm{m}^{2}$. The four fire load densities at the extreme right hand of the figure are for a bookstore, storage areas for the bookstore, a shoe store, and a greeting card shop. The total fire load of all fixed and movable combustibles ranges from 1,126 MJ to 511,413 MJ with a mean of 52,339 MJ. The results of the survey are summarized in Table 1 . The area of the surveyed stores ranged from $3.25 \mathrm{~m}^{2}$ to $1,707 \mathrm{~m}^{2}$.

Table 2 shows the contribution of four types of materials that are usually found in commercial premises textiles, plastics, wood/paper, and food items - to the total fire load for the commercial establishments surveyed. Combustibles that do not fit into these four material types are classified as 'miscellaneous'. 


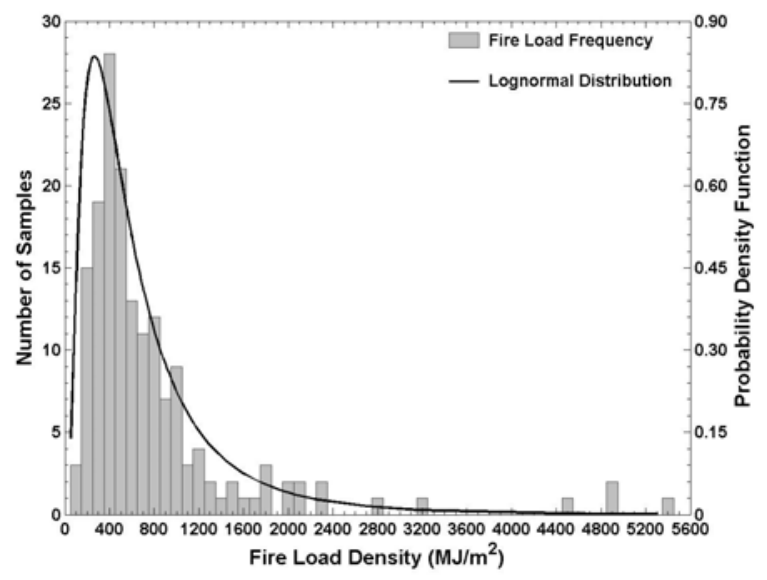

Fig. 1. Frequencies of fire load density of the 168 surveyed stores

Table 1. Floor area, fire load density and total fire load for all 168 stores in the survey.

\begin{tabular}{lllll}
\hline \hline & Mean & Range & Standard deviation & 95 $^{\text {th }}$ percentile \\
\hline Floor area $\left[\mathrm{m}^{2}\right]$ & 102 & $3.25-1,707$ & 183 & 333 \\
Fire load density $\left[\mathrm{MJ} / \mathrm{m}^{2}\right]$ & 747 & $56-5,305$ & 833 & 2,050 \\
Total Fire load $[\mathrm{MJ}]$ & 52,339 & $1,126-511,413$ & 77,166 & 167,383 \\
\hline \hline
\end{tabular}

Table 2. Contribution of types of combustibles to the fire loads of different stores

\begin{tabular}{|c|c|c|c|c|c|c|c|c|c|c|}
\hline \multirow[b]{3}{*}{ Group } & \multicolumn{10}{|c|}{ Contribution of Different Combustibles (\%) } \\
\hline & \multicolumn{2}{|c|}{ Textiles } & \multicolumn{2}{|c|}{ Plastics } & \multicolumn{2}{|c|}{ Wood/Paper } & \multicolumn{2}{|l|}{ Food } & \multicolumn{2}{|c|}{ Misc. } \\
\hline & 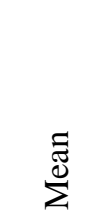 & 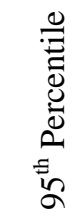 & 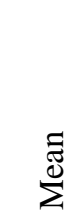 & 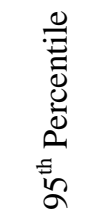 & 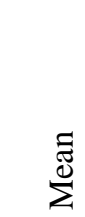 & 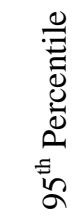 & $\sum_{\Sigma}^{\approx}$ & 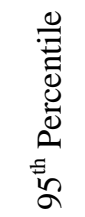 & 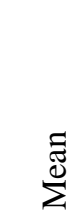 & 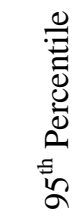 \\
\hline All Stores & 8.3 & 47 & 17.9 & 58.8 & 60.3 & 96.2 & 6.9 & 40.9 & 6.7 & 41.1 \\
\hline Shoe storage & 0.3 & -- & 0.8 & -- & 18.2 & -- & 0.0 & -- & 80.6 & -- \\
\hline Storage areas & 6.2 & 38.5 & 27.4 & 82.5 & 50.6 & 99.7 & 4.9 & 40.7 & 10.9 & 77.0 \\
\hline Fast-food outlets & 0.1 & 0.6 & 22.9 & 38.7 & 55.1 & 78.1 & 21.8 & 41.5 & 0.1 & 0.2 \\
\hline Clothing stores & 48.1 & 85 & 5.3 & 22.9 & 44.5 & 75.3 & 0.0 & 0.0 & 2.1 & 7.6 \\
\hline Restaurants & 3.7 & 13.1 & 5.2 & 10.0 & 84.0 & 94.9 & 2.2 & 11.1 & 4.8 & 23.3 \\
\hline Kitchens & 0.0 & 0.0 & 30.5 & 47.5 & 36.0 & 60.9 & 33.5 & 55.7 & 0.0 & 0.0 \\
\hline
\end{tabular}

\section{Fuel Packages}

Based on the analysis of the survey data, a number of fuel packages have been designed to represent fire load densities and types of combustibles of the different stores. Details of these packages are shown in Table 3. In Table 3 leather/rubber, which in Table 2 is included in the miscellaneous group, is defined separately as it was the main contributor to the fire load of the shoe store fuel package. Detailed discussion on these packages can be found in [13]. 
Table 3. Details of the fuel packages, their fire load densities and combustible materials

\begin{tabular}{|c|c|c|c|c|c|c|c|c|}
\hline \multirow{3}{*}{$\begin{array}{l}\text { Fuel } \\
\text { Package } \\
\text { Description }\end{array}$} & \multirow[b]{3}{*}{$\begin{array}{l}\text { Fuel } \\
\text { Package } \\
\text { ID }\end{array}$} & \multicolumn{6}{|c|}{ Combustible materials } & \multirow[b]{2}{*}{$\begin{array}{l}\text { Total } \\
\text { mass } \\
(\mathrm{kg})\end{array}$} \\
\hline & & & Textiles & Plastics & $\begin{array}{l}\text { Wood/ } \\
\text { paper }\end{array}$ & $\begin{array}{l}\text { Rubber/ } \\
\text { leather }\end{array}$ & $\begin{array}{l}\text { Food } \\
\text { products }\end{array}$ & \\
\hline & & $\left(\mathrm{MJ} / \mathrm{m}^{2}\right)$ & \multicolumn{6}{|c|}{ 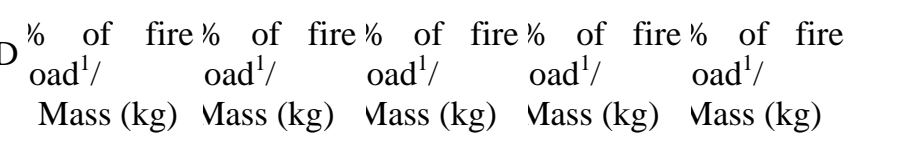 } \\
\hline $\begin{array}{l}\text { Computer } \\
\text { store }\end{array}$ & CMP-II & 812 & $\begin{array}{l}3.08 / \\
2.7\end{array}$ & $\begin{array}{l}50.6 / \\
18.9\end{array}$ & $\begin{array}{l}46.3 / \\
41.8\end{array}$ & $\begin{array}{l}0.00 / \\
0.0\end{array}$ & $\begin{array}{l}0.00 / \\
0.0\end{array}$ & 63.4 \\
\hline Storage area & SA-II & 2320 & $\begin{array}{l}5.60 / \\
13.7\end{array}$ & $\begin{array}{l}31.1 / \\
33.2\end{array}$ & $\begin{array}{l}49.1 / \\
128\end{array}$ & $\begin{array}{l}8.50 / \\
10.7\end{array}$ & $\begin{array}{l}5.70 / \\
18.5\end{array}$ & 204 \\
\hline $\begin{array}{l}\text { Clothing } \\
\text { store }\end{array}$ & CLC-II & 661 & $\begin{array}{l}86.0 / \\
61.4\end{array}$ & $\begin{array}{l}2.00 / \\
0.61\end{array}$ & $\begin{array}{l}12.0 / \\
8.81\end{array}$ & $\begin{array}{l}0.00 / \\
0.0\end{array}$ & $\begin{array}{l}0.00 / \\
0.0\end{array}$ & 70.9 \\
\hline Toy store & TOY-II & 1223 & $\begin{array}{l}6.59 / \\
8.72\end{array}$ & $\begin{array}{l}18.6 / \\
10.5\end{array}$ & $\begin{array}{l}74.8 / \\
102\end{array}$ & $\begin{array}{l}0.00 / \\
0.0\end{array}$ & $\begin{array}{l}0.00 / \\
0.0\end{array}$ & 121 \\
\hline Shoe store & SHO-II & 4900 & $\begin{array}{l}1.00 / \\
2.64\end{array}$ & $\begin{array}{l}0.00 / \\
0.0\end{array}$ & $\begin{array}{l}34.0 / \\
92.6\end{array}$ & $\begin{array}{l}65.0 / \\
120\end{array}$ & $\begin{array}{l}0.00 / \\
0.0\end{array}$ & 215 \\
\hline Bookstore & BK-II & 5305 & $\begin{array}{l}0.40 / \\
2.29\end{array}$ & $\begin{array}{l}0.00 / \\
0.0\end{array}$ & $\begin{array}{l}99.6 / \\
604\end{array}$ & $\begin{array}{l}0.00 / \\
0.0\end{array}$ & $\begin{array}{l}0.00 / \\
0.0\end{array}$ & 606 \\
\hline $\begin{array}{l}\text { Fast food } \\
\text { outlet }\end{array}$ & FF-II & 881 & $\begin{array}{l}0.30 / \\
0.284\end{array}$ & $\begin{array}{l}19.3 / \\
7.81\end{array}$ & $\begin{array}{l}38.9 / \\
38.1\end{array}$ & $\begin{array}{l}0.00 / \\
0.0\end{array}$ & $\begin{array}{l}41.5 / \\
17.4\end{array}$ & 63.6 \\
\hline
\end{tabular}

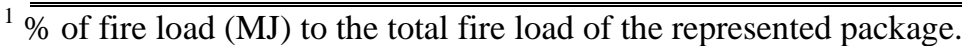

${ }^{2}$ total mass of combustible materials only, non-combustibles are not included.

\section{FULLY-DEVELOPED FIRE TESTS}

Using the identified fuel packages, a series of experiments were conducted to determine their burning characteristics and to develop data to characterize design fires for commercial premises. The facility used for these tests was located inside the burn-hall of the National Research Council of Canada (NRCC). The facility was constructed from non-combustible materials, with walls and ceiling lined with cement board and covered with sheets of ceramic fibres and the floor lined with cement tiles. The dimensions of the room were 3.6 x 2.7 x 2.4-m high, with a doorway $0.9-\mathrm{m}$ wide $\times 2.2-\mathrm{m}$ high. The door opened to an 11-m long corridor that was used to accommodate extended flames and to cool the smoke products before entering the exhaust duct. Fig. 2 shows the layout of the post-flashover facility. The facility was instrumented to measure gas temperatures inside the room and in the corridor, concentrations of $\mathrm{O}_{2}$, CO and $\mathrm{CO}_{2}$ in the duct, and heat fluxes inside the room.

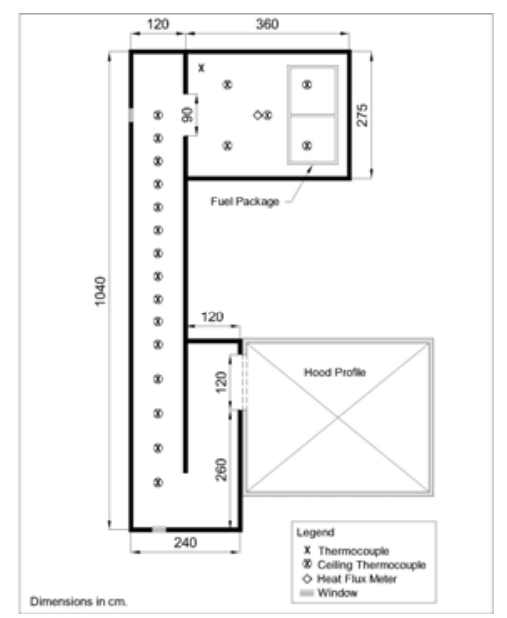

Fig. 2. Layout of the post-flashover test facility 
Experiments were conducted using fuel packages that covered $2.0 \mathrm{~m}^{2}$, with the exception of the shoe store test that had a fuel package of $1.0 \mathrm{~m}^{2}$. The reason for this is that in a preliminary shoe store test, the test had to be terminated 5 minutes after ignition because gas temperatures inside the duct exceeded the temperature for safe operation of the exhaust system. All packages were ignited using a $75-\mathrm{kW}$ propane Tburner running for 4 minutes to simulate an ignition source from a large wastepaper basket.

\section{Experimental Results}

The following sections provide a description of the tests setup, observations, and discussion of the results, such as HRR, hot layer temperature, heat fluxes and $\mathrm{CO}$ and $\mathrm{CO}_{2}$ concentration and production rates.

\section{Heat Release Rate}

The heat release rate of the tests was calculated using the oxygen depletion method based on measurements of gas temperature, mass flow rate, and concentrations of $\mathrm{O}_{2}, \mathrm{CO}$ and $\mathrm{CO}_{2}$ in the duct. It was assumed that when a $20^{\circ} \mathrm{C}$ temperature rise in the hot layer occurs, the fire becomes self-sustained and grows without the need for an external ignition source. For this reason, HRR and other data were plotted starting at the time when the hot layer temperature increased by $20^{\circ} \mathrm{C}$.

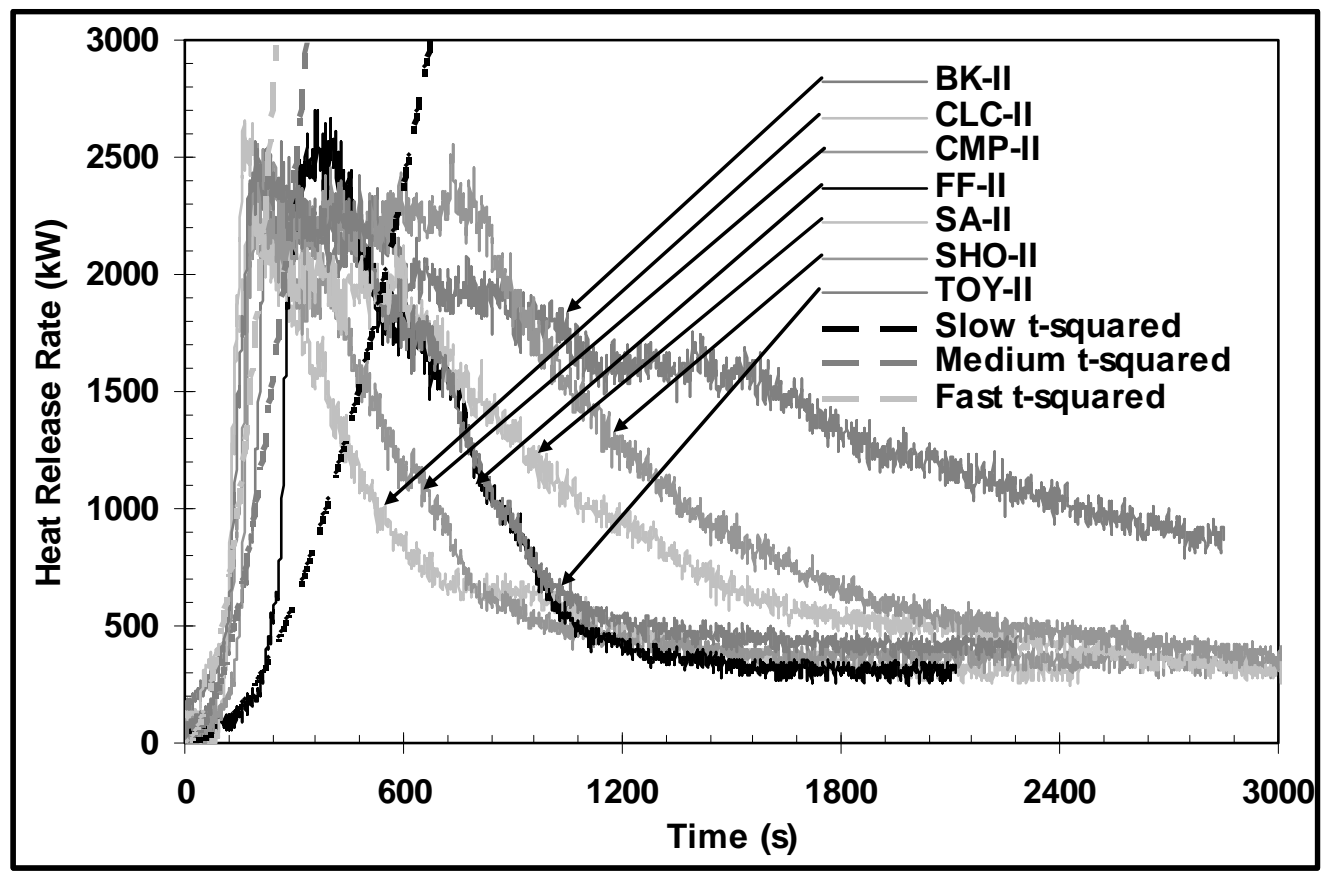

Fig. 3. Heat release rates of experiments

Figure 3 shows the heat release rate history of all tests from ignition to $3000 \mathrm{~s}$. The figure also includes three curves that represent Slow, Medium, and Fast t-squared fires. All tests have a peak HRR that ranges from 2.4 to $2.7 \mathrm{MW}$. The size of the door and the corridor contributed to limiting the amount of combustion air available in the room. As shown in the figure, the fire growth of the bookstore (BK-II), and the fast-food (FF-II) tests follows a Slow to Medium t-squared fire, while the clothing (CLS-II), shoe store (SHO-II), and computer store (CMP-II) tests grew as Medium to Fast t-squared fires. The growth rates of the toy store (TOY-II) and storage area (SA-II) tests followed a Fast t-squared fire. For most tests, the heat release rate stayed at levels above $2 \mathrm{MW}$ for about $8 \mathrm{~min}$. Only the heat release rate of the clothing store started to decrease right after it reached its peak value. The heat release rate of the bookstore decreased at a very slow rate followed by that of the shoe store and the storage area tests.

The experimental heat release rates were used to calculate the total heat released during the tests. As shown in Table 4 there is a difference between the theoretical and experimental results, which may be attributed to the following reasons: incomplete combustion due to ventilation-controlled conditions that led to lower experimental total heat release than the theoretical; not all combustibles were consumed during the 
fire; uncertainty about the composition of some combustibles; and smoke leakage from the test room, hood, and duct, that could have contributed to about $5 \%$ loss in the experimentally measured values of the total heat released.

Table 4. Heat released, growth rates and heat content

\begin{tabular}{|c|c|c|c|c|c|c|c|}
\hline \multirow[b]{2}{*}{ Test Title } & \multirow[b]{2}{*}{ Test ID } & \multicolumn{3}{|c|}{ Heat Release Data } & \multicolumn{2}{|c|}{$\begin{array}{l}\text { Total Heat } \\
\text { Content (MJ) }\end{array}$} & \multirow{2}{*}{$\begin{array}{l}\text { Average Heat } \\
\text { Content } \\
\text { (MJ/kg) } \\
\text { (Theoretical) }\end{array}$} \\
\hline & & 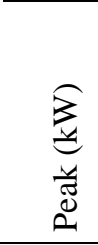 & 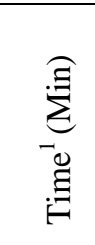 & 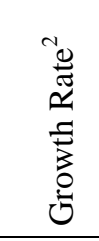 & 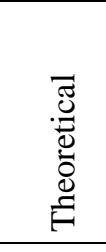 & 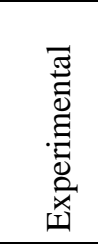 & \\
\hline Computer store & CMP-II & 2475 & $4: 10$ & $\mathrm{M}-\mathrm{F}$ & 1624 & 2100 & 25.6 \\
\hline Storage area & SA-II & 2385 & $2: 45$ & $\mathrm{~F}$ & 4640 & 2751 & 22.7 \\
\hline Clothing store & CLC-II & 2660 & 3:30 & M-F & 1322 & 1610 & 19.1 \\
\hline Toy store & TOY-II & 2570 & $4: 15$ & $\mathrm{~F}$ & 2446 & 2125 & 20.2 \\
\hline Shoe store & SHO-II & 2555 & 4:00 & M-F & 4900 & 3990 & 22.8 \\
\hline Bookstore & BK-II & 2375 & $2: 50$ & S-M & 10610 & 4154 & 17.5 \\
\hline Fast food outlet & FF-II & 2700 & 6:15 & S-M & 1762 & 1660 & 27.7 \\
\hline
\end{tabular}

\section{Hot Layer Temperature and Heat Fluxes}

K-Type thermocouples were used to measure gas temperatures at the following locations: at the corner of the burn room; at the ceiling level in the burn room; at the ceiling level along the corridor; and in the duct. The thermocouple tree at the corner of the room was a good indicator of the hot layer temperature, and these thermocouples were used for the analysis below. The thermocouples at the ceiling level, especially the thermocouples above the fire, and the thermocouple tree in the middle of the room, were affected by direct flame impingement and the temperatures were much higher than those of the hot layer temperature. The thermocouples along the corridor were used to assess the cooling of the smoke leaving the burn room along the corridor and whether combustion was taking place in the corridor.

The experimental hot layer temperatures are shown in Fig. 4 and peak temperatures at various locations in Table 5. Peak hot layer temperatures ranged from 1010 to $1210^{\circ} \mathrm{C}$. The highest temperature was measured during the shoe store test (SHO-II) and the lowest temperature during the clothing test (CLC-II).

Heat flux values are presented in Table 5 and Fig. 5. Heat flux values ranged from 77 to $207 \mathrm{~kW} / \mathrm{m}^{2}$. Using the $600^{\circ} \mathrm{C}$ and the $21 \mathrm{~kW} / \mathrm{m}^{2}$ heat flux flashover criterion, the hot layer temperatures and heat flux measurements indicate that flashover conditions occurred in all experiments within 4 minutes from ignition. The heat flux of the shoe store dropped sharply to zero at about $750 \mathrm{~s}$ and after $120 \mathrm{~s}$ it increased to where it should have been. This drop was due to debris that covered the heat flux sensor, which was eventually removed. As a result of debris covering the sensor the heat flux data of the bookstore dropped to zero at about $500 \mathrm{~s}$.

Corridor temperatures presented in Table 5 indicate that the temperatures in the corridor at $0.5 \mathrm{~m}$ and $3.5 \mathrm{~m}$ from the door were almost the same as the temperatures of the hot layer inside the burn room. For most tests, the temperatures in the corridor at $6.5 \mathrm{~m}$ away from the room decreased by up to $200^{\circ} \mathrm{C}$. During the shoe store (SHO-II) and the fast food (FF-II) tests, the recorded temperatures in the corridor were higher than the temperatures of the hot layer inside the room indicating that combustion was also taking place in the corridor. Combustion in the corridor during the shoe store test, extended for a long distance from the door causing the temperature at $6.5 \mathrm{~m}$ to be higher than the temperature at $3.5 \mathrm{~m}$.

\section{Gas Concentrations and Production Rates}

Concentrations of $\mathrm{CO}_{2}$ for all tests are shown in Fig. 6. Concentration curves follow the same trend as the heat release rates, with maximum values reaching 4 to $5.1 \%$. Concentrations for the bookstore, the highest in fuel load, test are the highest of all tests and those of the clothing store test, the lowest in fuel load, are the lowest. 
Table 5. Hot layer temperature and heat flux values

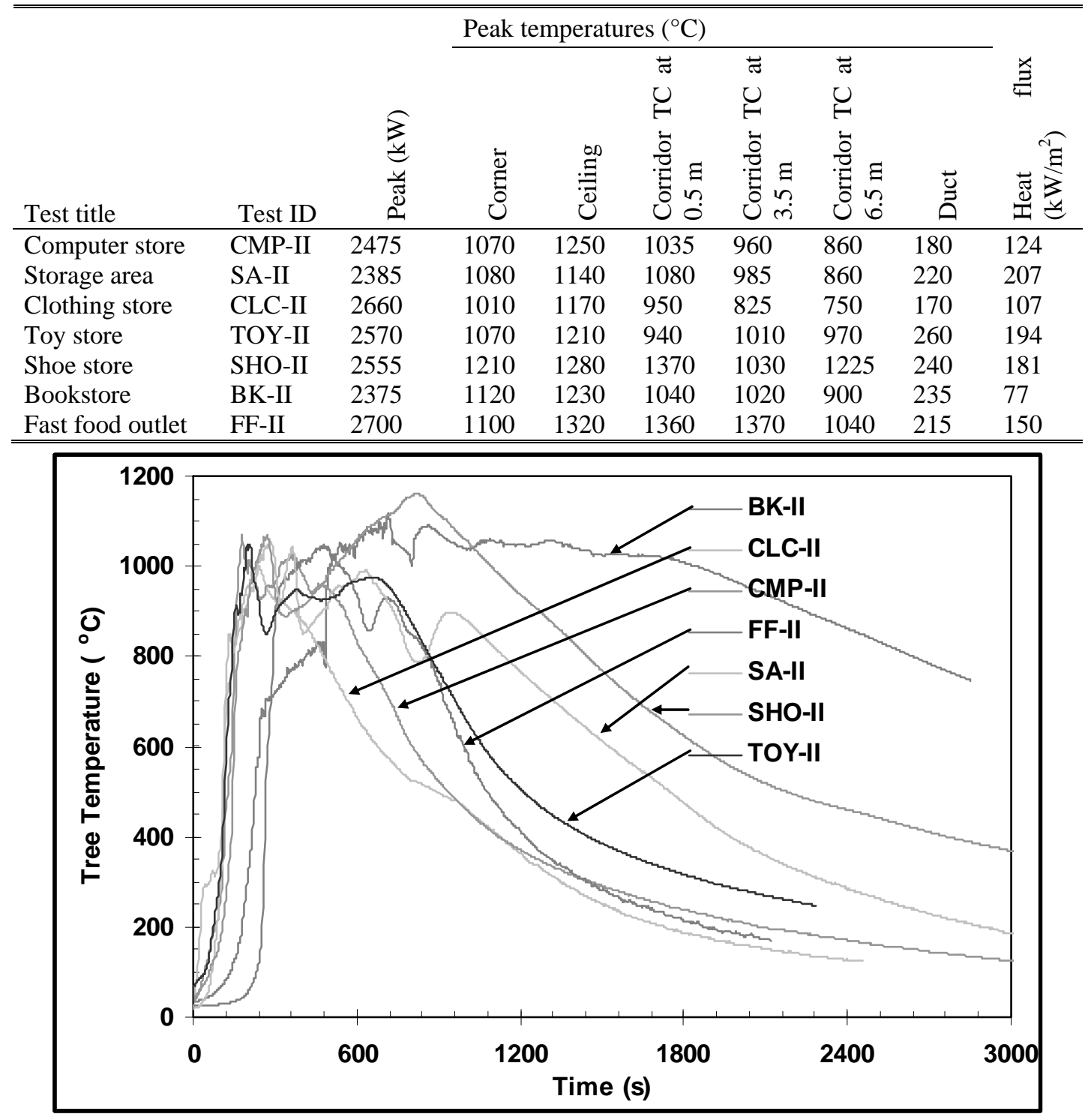

Fig. 4. Hot layer temperatures in the fire room 


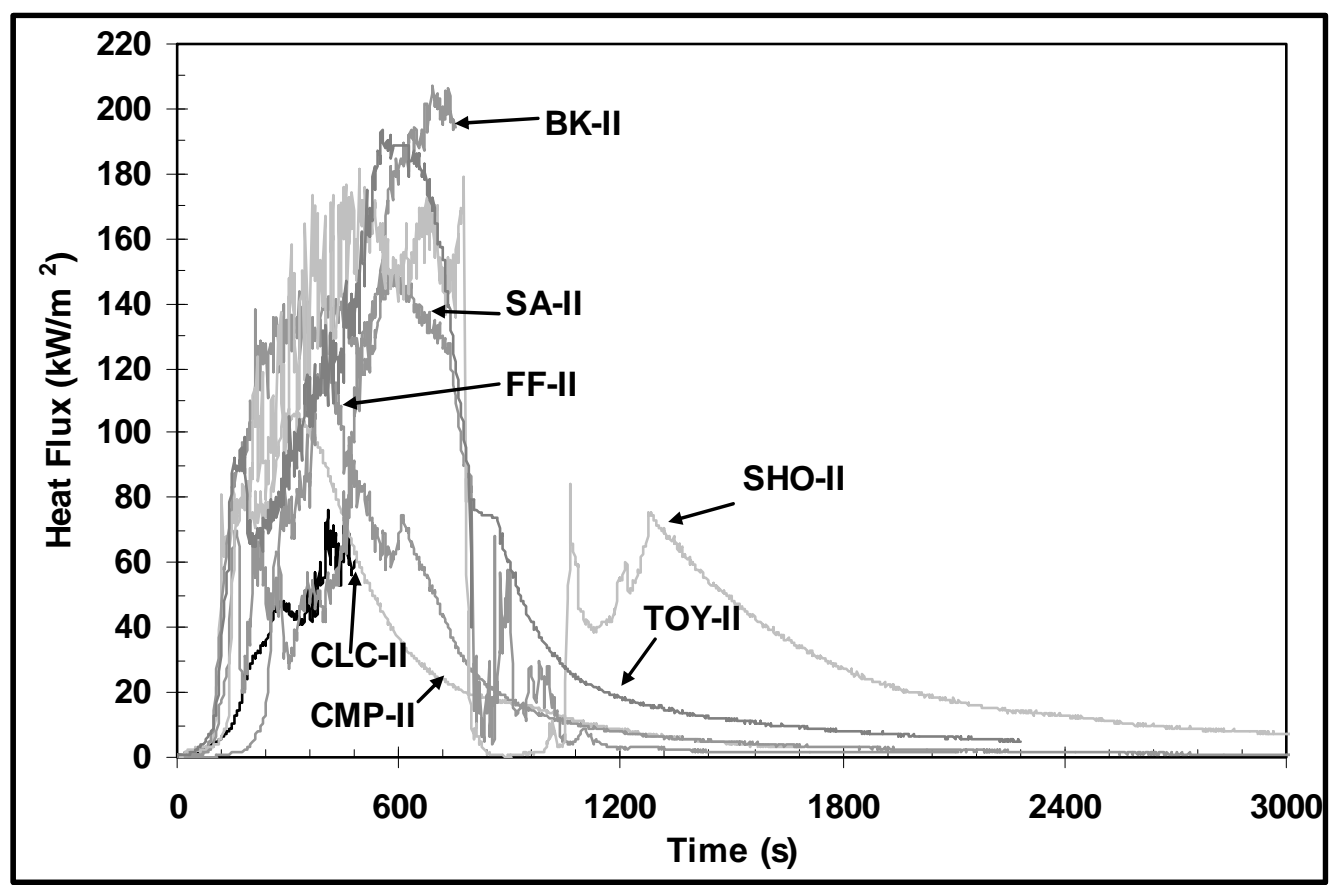

Fig. 5. Heat flux measurements in the fire room

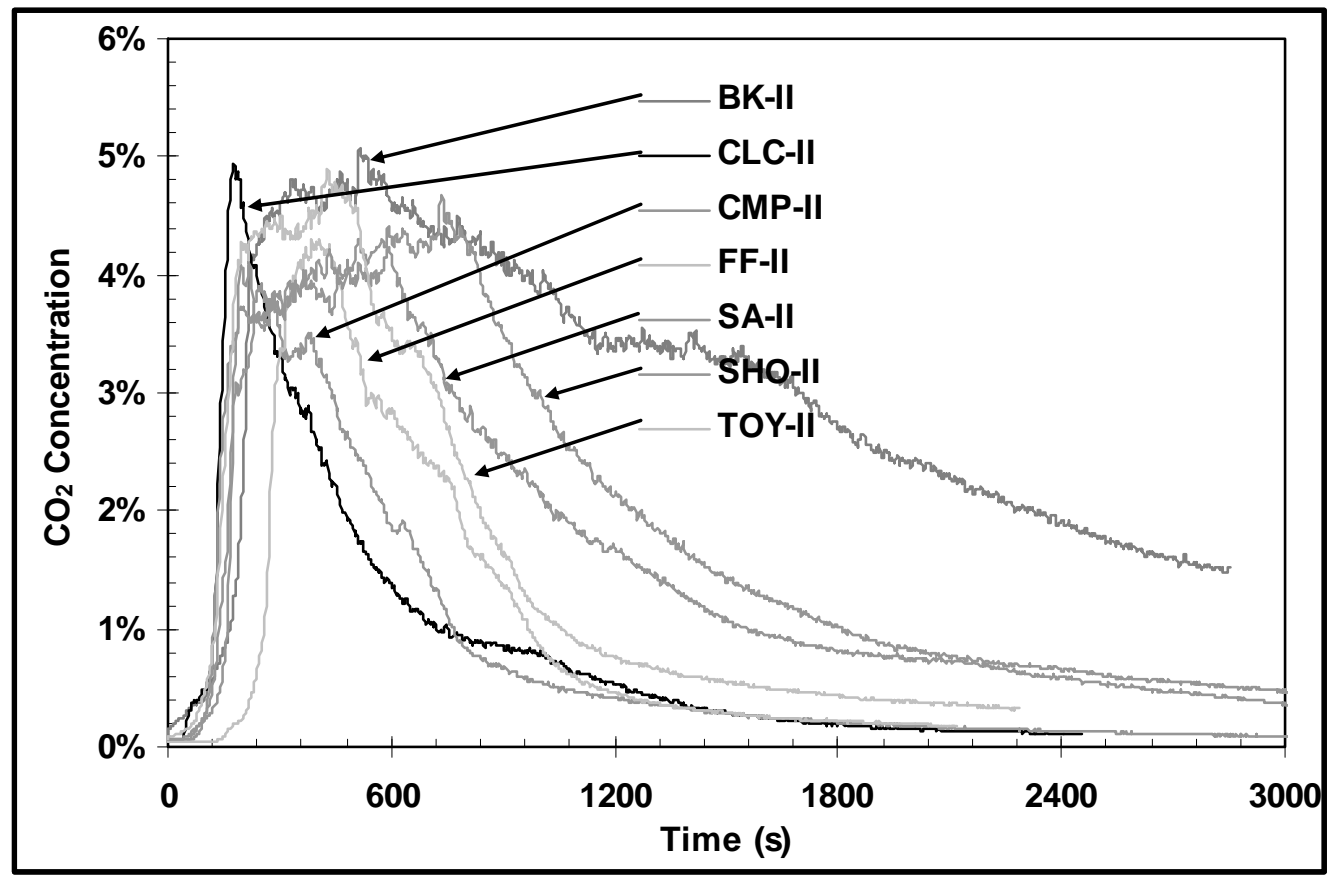

Fig. 6. Carbon dioxide concentrations 


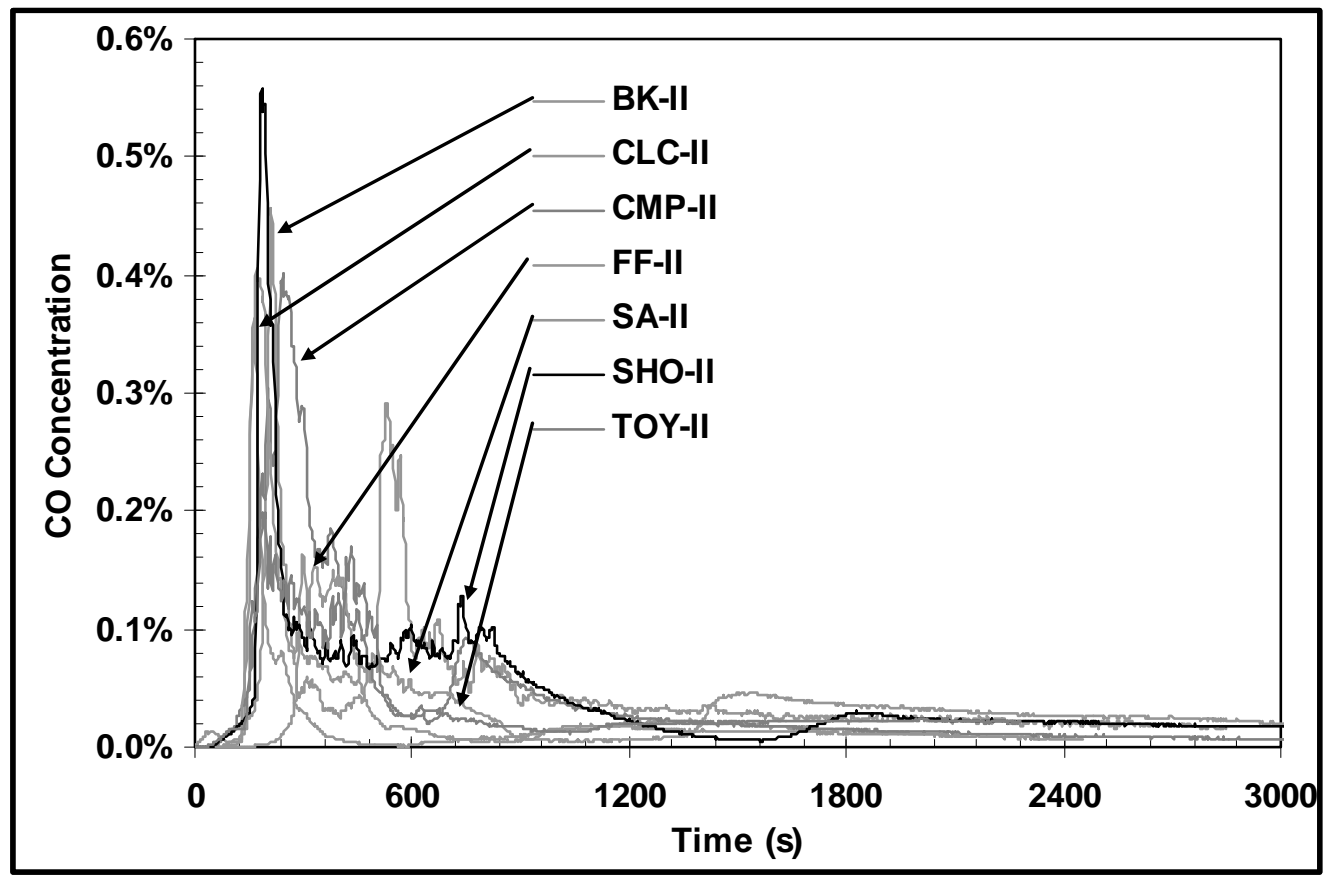

Fig. 7. Carbon monoxide concentrations

Carbon monoxide concentrations depicted in Fig. 7 show a fast increase during the growth phase of the tests followed by a sharp decrease after reaching peak values. For most tests CO concentrations remain at about $1000 \mathrm{ppm}$ for a period of $10 \mathrm{~min}$ and then dropped down to about $300 \mathrm{ppm}$.

Table 6. Maximum $\mathrm{CO}$ and $\mathrm{CO}_{2}$ concentrations and average production rates

\begin{tabular}{|c|c|c|c|c|c|}
\hline \multirow[b]{2}{*}{ Test title } & \multirow[b]{2}{*}{ Test ID } & \multicolumn{4}{|c|}{$\mathrm{CO}$ and $\mathrm{CO}_{2}$ Data } \\
\hline & & $\begin{array}{l}\text { Maximum } \\
\text { CO (ppm) }\end{array}$ & $\begin{array}{l}\text { Average CO } \\
\text { production } \\
(\mathrm{mg} / \mathrm{kJ})\end{array}$ & $\begin{array}{l}\text { Maximu } \\
\mathrm{m} \quad \mathrm{CO}_{2} \\
(\%)\end{array}$ & $\begin{array}{l}\text { Average } \\
\mathrm{CO}_{2} \\
\text { production } \\
(\mathrm{mg} / \mathrm{kJ})\end{array}$ \\
\hline Computer store & CMP-II & 4015 & 2.9 & 4.0 & 52 \\
\hline Storage area & SA-II & 4050 & 2.1 & 4.0 & 84 \\
\hline Clothing store & CLC-II & 3640 & 1.3 & 4.9 & 63 \\
\hline Toy store & TOY-II & 1994 & 1.9 & 4.9 & 82 \\
\hline Shoe store $^{1}$ & SHO-II ${ }^{1}$ & 5576 & 2.0 & 4.7 & 78 \\
\hline Bookstore & BK-II & 4560 & 1.4 & 5.1 & 99 \\
\hline Fast food outlet & FF-II & 1640 & 1.3 & 4.3 & 68 \\
\hline
\end{tabular}

${ }^{1}$ fuel package area $=1 \mathrm{~m}^{2}$

Table 6 presents maximum $\mathrm{CO}$ and $\mathrm{CO}_{2}$ concentrations, as well as average production rates. The production rates were computed by dividing the mass flow rate of $\mathrm{CO}$ and $\mathrm{CO}_{2}$ by the heat release rate. $\mathrm{CO}$ and $\mathrm{CO}_{2}$ production rates are also plotted in Figs. 8 and 9 respectively. Average $\mathrm{CO}$ production rates were calculated for each fuel package during four different fire stages: growth; ventilation-controlled; fuelcontrolled, early decay; and smouldering, late decay. During the growth stage, production rates ranged from 0.2 to $2.3 \mathrm{mg} / \mathrm{kJ}$, while during the ventilation-controlled period they ranged between 1.7 and 4.8 $\mathrm{mg} / \mathrm{kJ}$. Values during the fuel-controlled stage were between 0.4 to $1.6 \mathrm{mg} / \mathrm{kJ}$ and during the smouldering phase were between 1.1 to $3.2 \mathrm{mg} / \mathrm{kJ}$. It is clear from Fig. 8 and Table 7 that CO production rates were very low during the growth phase and the early decay phase. During the post-flashover fully-developed phase, the average CO production was the highest for all fuel packages, with a peak value that is two to four times the average. From the table it can also be seen that $\mathrm{CO}$ production rates during smouldering 
conditions were higher than during flaming conditions. Comparing CO production rates of the different fuel packages during the ventilation-controlled conditions, it is clear that shoe stores, computer stores, and storage areas, which had high plastics and rubber contribution, had the highest CO production rates, while packages high in cellulosic materials had the lowest CO production rates.

$\mathrm{CO}_{2}$ production rates shown in Fig. 9 rise sharply and reach up to $100 \mathrm{mg} / \mathrm{kJ}$ within the first minute of the test and then they decrease to about $60 \mathrm{mg} / \mathrm{kJ}$. After this, they rise to a peak value and from there they decrease slowly until the end of the test. The bookstore test has the highest values followed by the shoe and storage area tests.

Table 7. Average production rates of carbon monoxide

\begin{tabular}{|c|c|c|c|c|c|c|}
\hline \multirow[b]{3}{*}{ Test title } & \multirow[b]{3}{*}{ Test ID } & \multicolumn{5}{|c|}{ Production at different stages $(\mathrm{mg} / \mathrm{kJ})$} \\
\hline & & \multirow{2}{*}{ 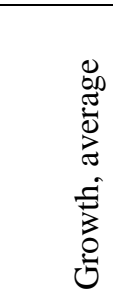 } & \multicolumn{2}{|c|}{$\begin{array}{l}\text { Ventilation } \\
\text { controlled }\end{array}$} & \multirow{2}{*}{ 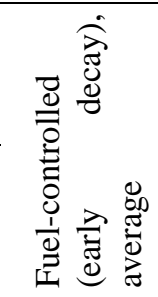 } & \multirow{2}{*}{ 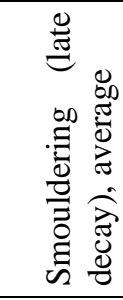 } \\
\hline & & & 女 & 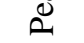 & & \\
\hline Computer store & CMP-II & 2.3 & 3.8 & 8.2 & 1.6 & 1.6 \\
\hline Storage area & SA-II & 1.0 & 4.8 & 9.2 & 1.0 & 3.2 \\
\hline Clothing store & CLC-II & 0.2 & 3.0 & 6.7 & 0.5 & 1.8 \\
\hline Toy store & TOY-II & 0.2 & 2.4 & 4.0 & 0.9 & 2.3 \\
\hline Shoe store & SHO-II & 0.3 & 4.5 & 12.3 & 1.3 & 2.2 \\
\hline Bookstore & BK-II & 1.5 & 2.8 & 11.7 & 1.1 & 1.1 \\
\hline Fast food outlet & FF-II & 0.2 & 1.7 & 3.5 & 0.4 & 1.8 \\
\hline
\end{tabular}

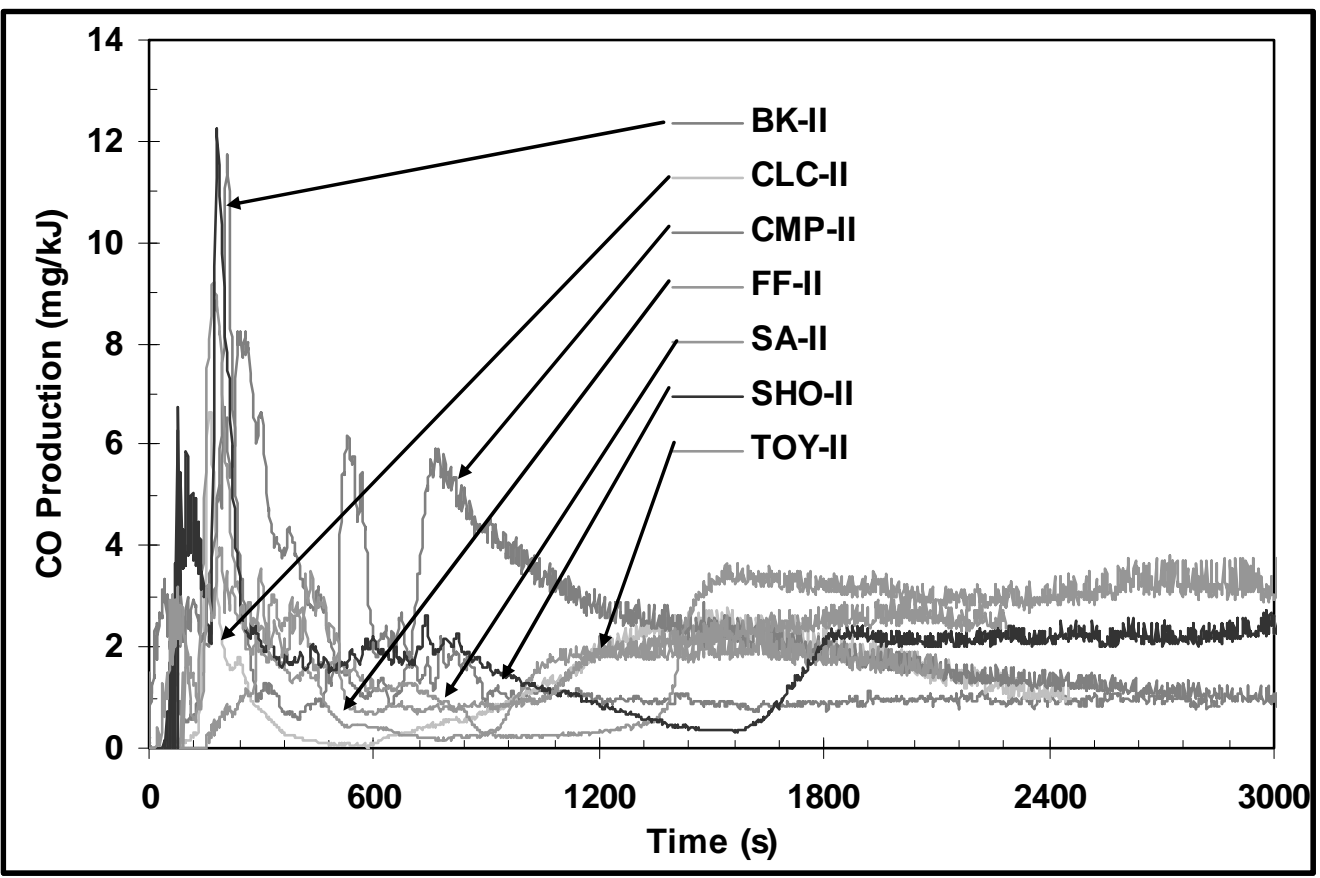

Fig. 8. Carbon monoxide production rates 


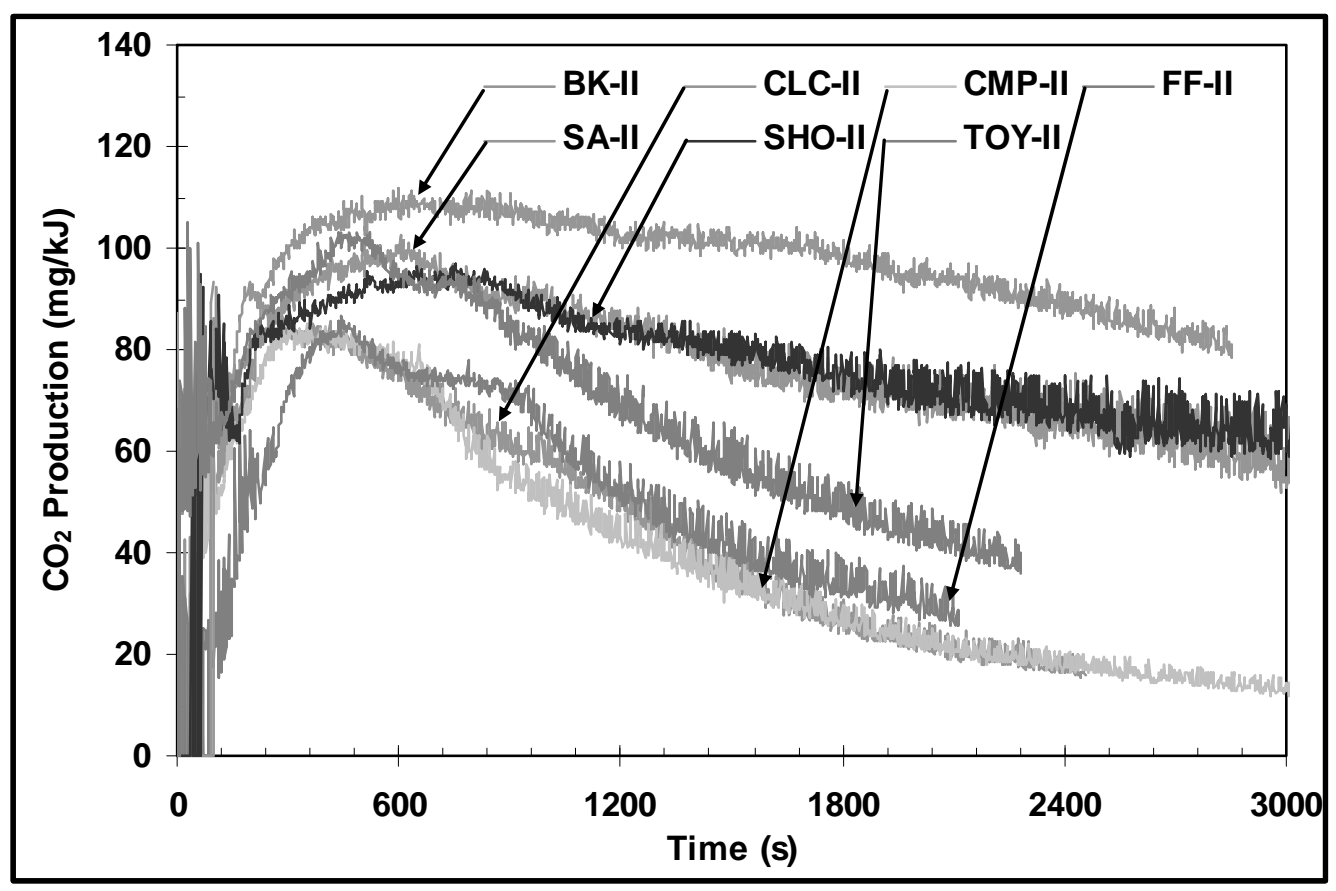

Fig. 9. Carbon dioxide production rates

\section{COMPUTER MODELLING}

The computer model FDS [8] was used to simulate the tests and also to predict a fire in a real size store. For this, a series of preliminary non-flashover experiments were performed using the fuel packages developed in this study. The results of these experiments were used to develop input data files for FDS, such that the model can give predictions that compare well with the data obtained from these experiments. One set of input data that represents the toy store fuel package is shown in Appendix A. Using these data files, FDS was then employed to simulate the post-flashover experiments described earlier in this paper. In addition, FDS was used to simulate a fire in a real size toy store. The results of these simulations are described in this section.

Figure 10 shows the heat release rate predicted by FDS for the preliminary experiment where a single package was used and the post-flashover test that had two fuel packages. As the figure shows FDS predicts satisfactorily the peak heat release rate, time to peak and the overall shape of the curve. A good result was also obtained for the temperatures in the compartment of the post-flashover test as shown in Fig. 11.

Finally FDS was used to predict a fire in a toy store with dimensions of $10 \mathrm{~m}$ x $10 \mathrm{~m}$ by $2.6 \mathrm{~m}$ high. The store had two opening $6 \mathrm{~m} \times 2.1 \mathrm{~m}$ height each that were kept open during the simulation. The toy store was filled with the toy store fuel packages developed in this study. In total, 100 fuel packages were specified as shown in Fig. 12.

The results of these runs are shown in Figs. 13 and 14. Figure 13 depicts the heat release rate of this fire which reached a peak value of $51 \mathrm{MW}$ and then started to decrease. The slow decrease is a result of the fact that the fire was a travelling fire that was moving slowly from the area near the openings towards the far corner of the store. The peak value compares well with the value of $54 \mathrm{MW}$ obtained using the ventilation controlled correlation:

$$
H R R=1.518 A_{\circ} \sqrt{H_{\circ}}
$$

Where, $A_{\circ}=$ weighted average of all openings $\left(\mathrm{m}^{2}\right)$, and $H_{\circ}=$ weighted average of all openings height (m). The fire burned for about $30 \mathrm{~min}$ with heat release rates over $30 \mathrm{MW}$, and then the heat release rate started to decrease until in burn out at about $50 \mathrm{~min}$. 
Figure 14 depicts the predicted temperatures of the toy store simulation, which reached a peak value of about $1200^{\circ} \mathrm{C}$. The temperature predictions are at the same levels as the temperatures measured during the tests.

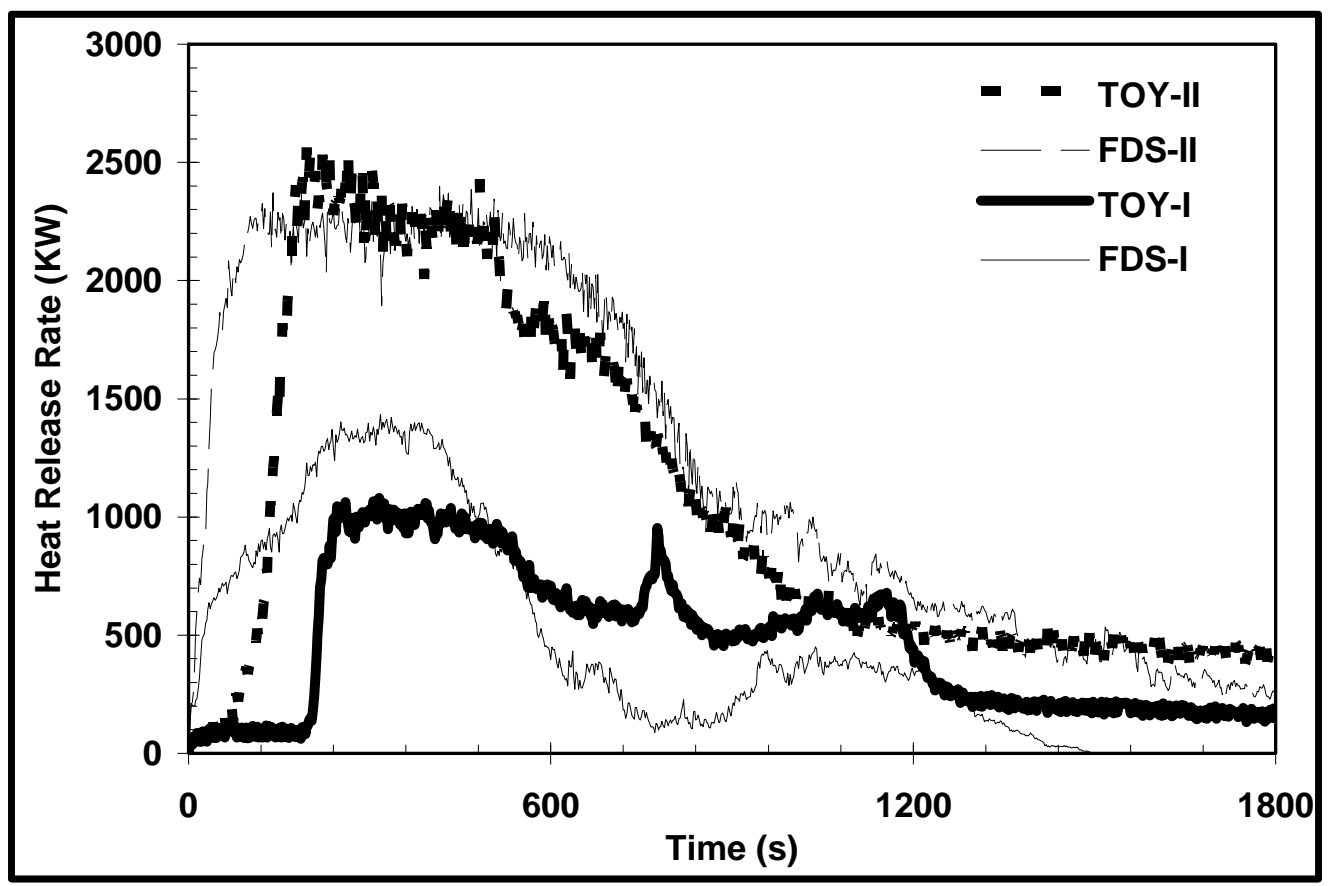

Fig. 10. Experimental and predicted heat release rate of toy store packages

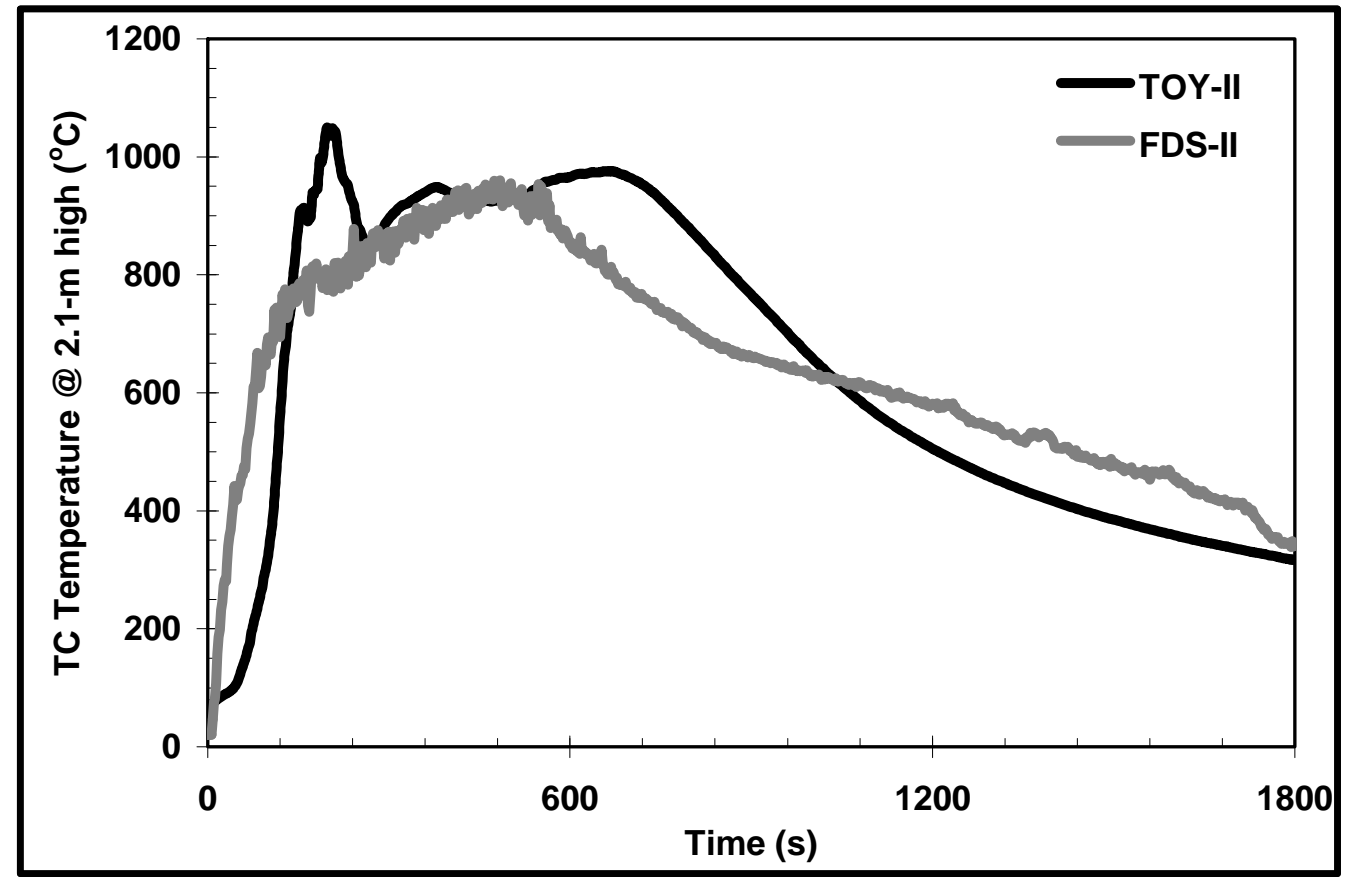

Fig. 11. Experimental and predicted temperatures of toy store package 


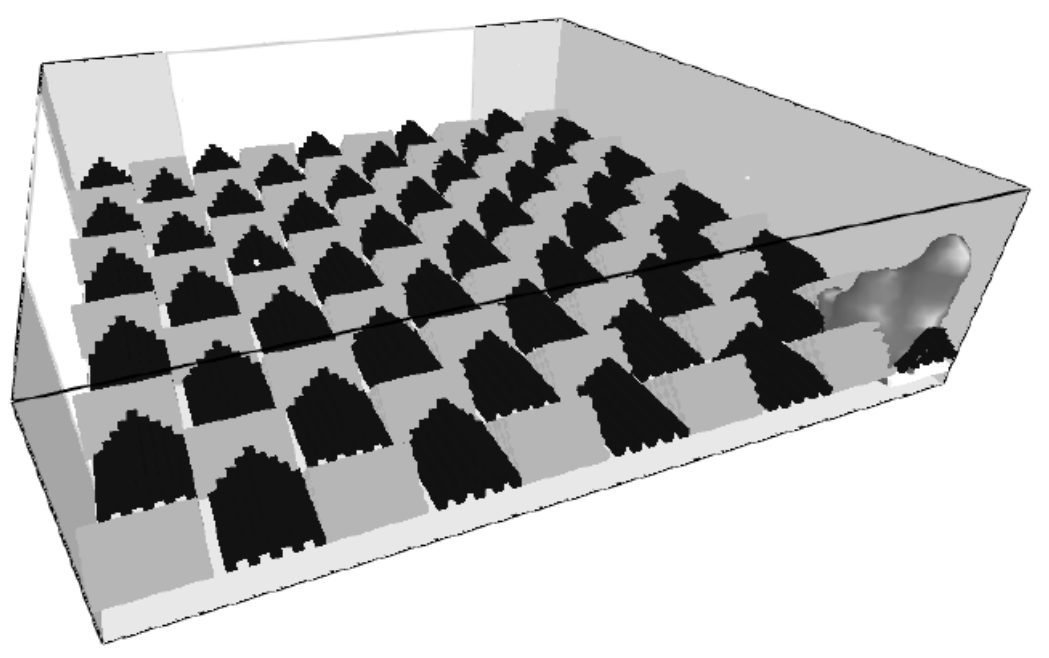

Fig. 12. FDS simulation of $10 \times 10 \mathrm{~m}$ toy store

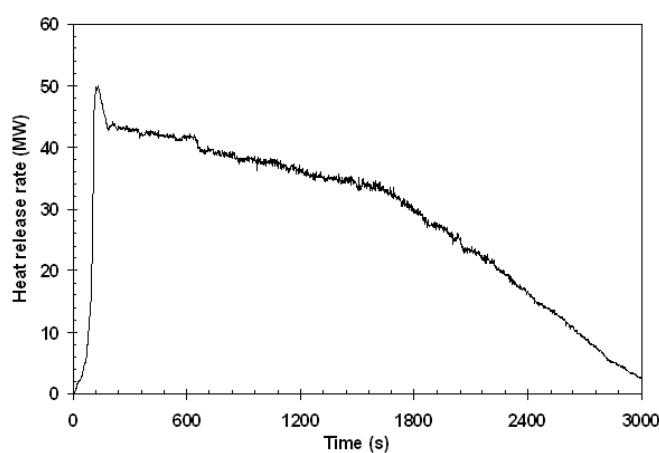

Fig. 13. FDS predicted heat release rate of toy store fire simulation

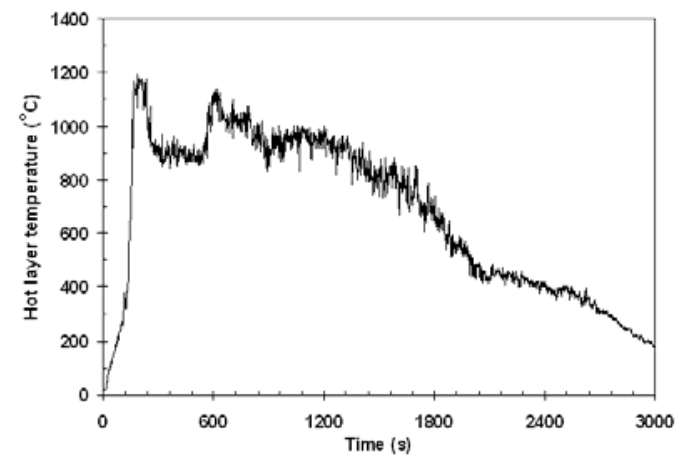

Fig. 14. FDS predicted hot layer temperature of toy store fire simulation

\section{CONCLUSIONS}

This paper presented a study done to develop design fires for commercial buildings. The study involved a survey of fire loads of commercial buildings, development of fuel packages representing fire loads and types of combustibles of these buildings and computer modelling. The conclusions that can be drawn from this work are the following:

- Fire loads in commercial buildings have a lognormal distribution with a mean of $747 \mathrm{MJ} / \mathrm{m}^{2}$, a maximum of $5305 \mathrm{MJ} / \mathrm{m}^{2}$, a minimum of $56 \mathrm{MJ} / \mathrm{m}^{2}$ and a standard deviation of $832 \mathrm{MJ} / \mathrm{m}^{2}$.

- Seven fuel packages can be used to represent the characteristics of fire loads and combustible materials in commercial buildings.

- The study showed that the main differences between the different fuel packages are the fire growth rate, the time to reach peak heat release rates, and the production rates of $\mathrm{CO}$ and $\mathrm{CO}_{2}$.

- Some packages produced a lot of combustible vapors that resulted in combustion extending outside the room of fire.

- The computer modeling exercise showed that, with a proper definition of the fuel packages, FDS can be used to simulate the fire development in buildings producing good heat release rate and temperature predictions. 


\section{REFERENCES}

[1] SFPE Engineering Guide to Performance-Based Fire Protection Analysis and Design of Buildings, Society of Fire Protection Engineers.

[2] International Fire Engineering Guidelines, Edition 2005, ISBN 1741614 562, 2005

[3] Fire Safety Engineering - Selection of Design Fire Scenarios and Design Fires, ISO/TC92SC4/WG6, 2005

[4] Yung, D.Y. and Benichou, N., How Design Fires Can be Used in Fire Hazard Analysis, Fire Technology, 38, 231-242, 2002, doi:10.1023/A:1019830015147

[5] Hadjisophocleous, G.V., Yung, D.T., Parametric study of the NRCC fire risk-cost assessment model for apartment and office buildings, Fourth International Symposium on Fire Safety Science (Ottawa, Ont., Canada, 7/13/1994), pp. 829-840, 1994

[6] Thomas, I., and Bennetts, I., The Development of Design Fires for Buildings. Fire Safety Engineering: Issues and Solutions, Sydney, Australia, 2004

[7] Rein, G., Torrero, J.L., and Lane, B., On the Design Fire for Non-Conventional Structures, Advanced Research Workshop Fire Computer Modelling, Santander, Spain, pp 15-28, 2007

[8] McGrattan, K. and G. Forney, Fire Dynamics Simulator (Version 4) User's Guide, U.S. Government Printing Office, Washington DC USA 20402 202-512-1800, NIST Special Publication 1019,_2005

[9] Chen, Z., Hadjisophocleous, G. and Zalok, E., A Survey of Fire Loads in Motels and Hotels, 3rd International Symposium on the $21^{\text {st }}$ century Center of Excellence Program, Tokyo University of Science, Japan, 2008

[10]Buchanan, A.H., Fire engineering design guide, 2001, centre of advanced engineering, University of Canterbury, New Zealand

[11] Yii, Y. W., Effect of Surface Area and Thickness on Fire Loads, Fire Engineering Research Report, School of Engineering, University of Canterbury, Christchurch, New Zealand, 2000/13, ISSN 11735996.

[12]Thomas, P. H., Design Guide: Structure Fire Safety CIB W14 workshop report, Fire Safety Journal, Vol. 10, No. 2, pp. 77-137, 1986, doi:10.1016/0379-7112(86)90041-X

[13]Zalok, E., Development of Design Fires for Commercial Premises, PhD Thesis, Carleton University, 2006

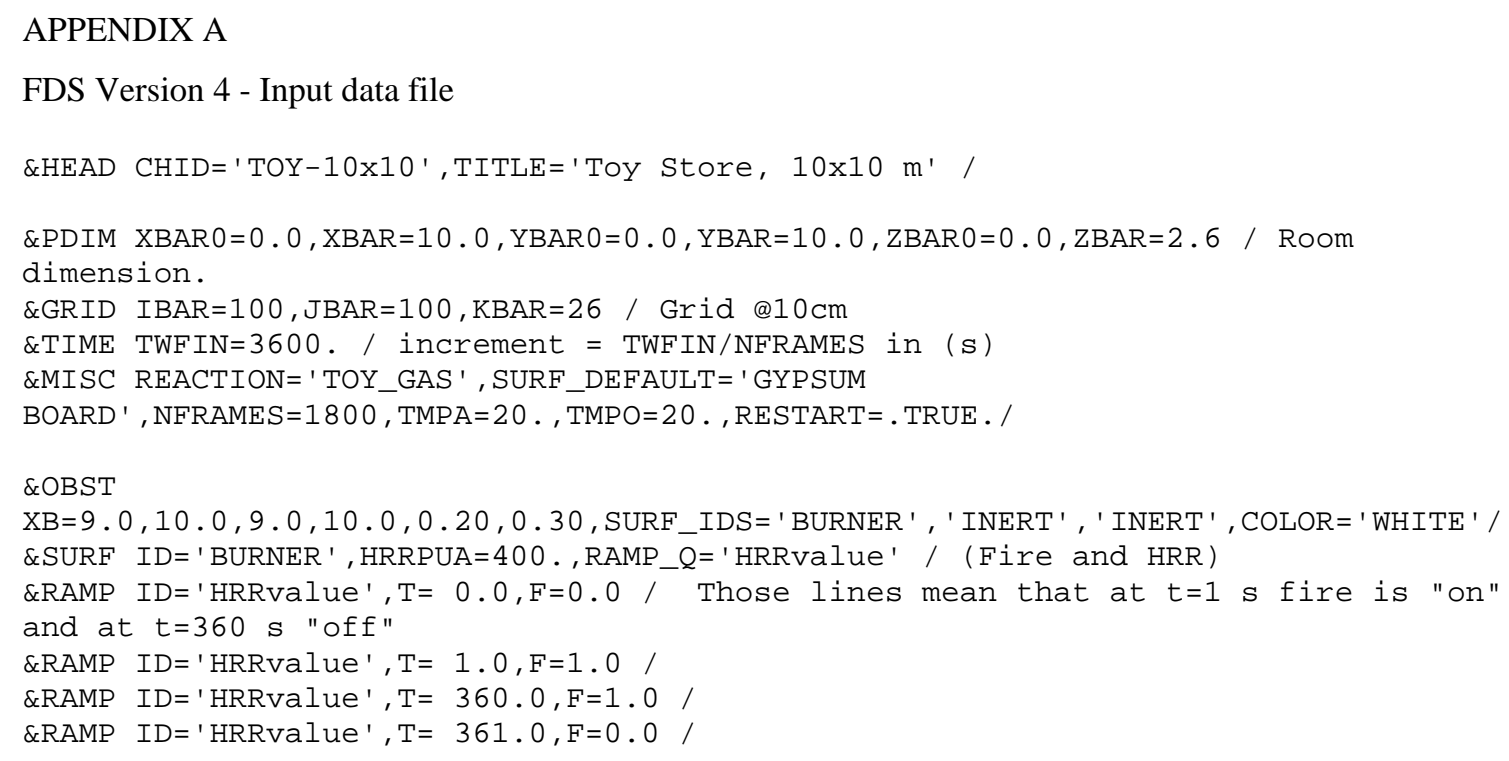


\&VENT XB=2.๑, 8.๑, $. \odot, \odot . \odot, \odot . \odot, 2.6$, SURF_ID="OPEN" / Exit door

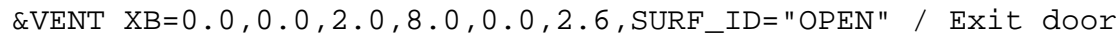

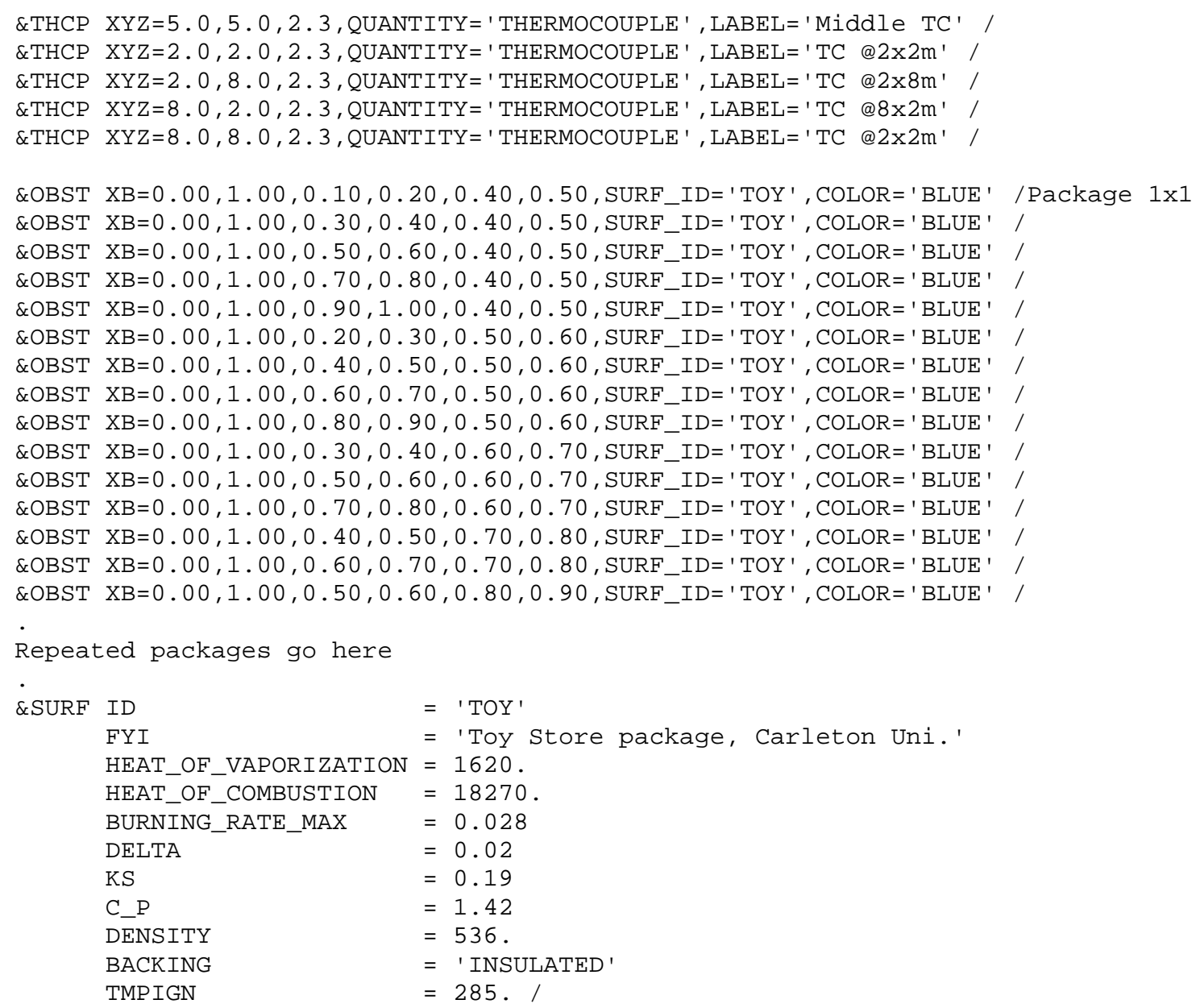

